\title{
DOES PUBLIC APPROVAL SHAPE NEWS? COMPETING LEGITIMACIES AND NEWS HEADLINES IN THE PHILIPPINES FROM RAMOS TO AQUINO III
}

\author{
Gabrielle Ann S. Mendoza* \\ Department of Political Science, College of Social Sciences and Philosophy, \\ Bulwagang Silangang Palma, University of the Philippines Diliman, \\ Quezon City, 1001 Philippines \\ E-mail: gabrielleannsm@gmail.com \\ Rogelio Alicor L. Panao ${ }^{* *}$ \\ Department of Political Science, College of Social Sciences and Philosophy, \\ Bulwagang Silangang Palma, University of the Philippines Diliman, \\ Quezon City, 1001 Philippines \\ E-mail: rlpanao@up.edu.ph
}

Published online: 15 January 2021

To cite this article: Mendoza, G. A. S. and Panao, R. A. L. 2021. Does public approval shape news? Competing legitimacies and news headlines in the Philippines from Ramos to Aquino III. International Journal of Asia Pacific Studies 17 (1): 29-55. https://doi.org/10.21315/ijaps2021.17.1.2

To link to this article: https://doi.org/10.21315/ijaps2021.17.1.2

\begin{abstract}
Can a president's high public approval, vis-à-vis competing coordinate institutions, shape press coverage of political events? Testing theories of executive scandals, this paper argues that in the context of Philippine presidential democracy, presidential satisfaction shapes the production of political events more than the presence of other policy issues competing for broadsheet space. Using logistic regression models to analyse the news headlines appearing in two major broadsheets in the Philippines from 1992 to 2016, the study finds that presidents whose approval ratings are low compared to Congress are an easy target for the opposition and a much more attractive topic for sensational news by the press. With a much smaller circle of supporters for the president, there is also less risk for the opposition and
\end{abstract}


the press collaborating or colluding in the production of political events. The press, in contrast, tends to be conservative in reporting political events when the public mood is generally supportive of the Philippine chief executive.

Keywords: Executive-legislative relations, Philippines, president, press, scandals

\section{INTRODUCTION}

Can a president's high public approval, vis-à-vis competing coordinate institutions, shape press coverage of political events?

Executive-legislative relations in presidential democracies are transactional by nature (Shugart 2006). With both branches of government elected independently with fixed terms, the executive and the legislature can pursue different policy objectives while still claiming the mandate of the people. The president, dealing with high and contradicting expectations, would have to resort to bargaining with the Congress in order to maintain power and facilitate cooperation in policymaking (Neustadt 1990). Philippine scholars have studied this in the form of pork-barrel distributions and the president's use of constitutional powers (Kasuya 2005; Kawanaka 2010; Panao 2014). Beyond this, Neustadt (1990) points out that presidential popularity is a key source of bargaining power for the president. Because politicians anticipate the sentiment of voters, their relative power in negotiating with the president is mediated by the president's reputation.

Public allegations of misconduct and congressional investigations are then significant avenues for political competition due to their ability to challenge the public image of incumbents. In emerging democracies such as the Philippines, politics is not driven by performance alone but also by reputation and personality (Thompson 2000). Political events, such as scandals and crises, can be weaponised by the opposition to delegitimise incumbents (Simon and Ostrom 1989; Green et al. 2018; De Neve et al. 2018) and mobilise citizens towards change (Claudio 2014; Dixon 2018). In the Philippines, an independent and critical press is recognised not only for its role in restoring democracy but for putting government mishaps into public scrutiny (Ables 2003; Coronel 2010). By infusing events with symbolic meanings, newspapers can weave stories into people's collective narratives (Edelman 1988; Boomgaarden et al. 2011). But Philippine newspapers have also been criticised for privileging the interests of the elites. Moreover, despite being regarded as the freest in Southeast Asia, the practice of journalism 
in the Philippines is also considered the most dangerous due to media killings, harassment and the constant threat of libel hurled against journalists (Coronel 2010; Center for Media Freedom and Responsibility [CMFR] 2005). These occupational hazards, along with the concentration of media ownership to a small circle of conglomerates, make journalists vulnerable to bribery and corruption (Coronel, 2001). With newspapers as conduits by which elites skew public opinion in post-People Power Revolution (EDSA) Philippines, newspapers are no longer just harbingers of information but instruments of political power (Coronel 2001; Pertierra 2012).

Testing theories of executive scandals (Nyhan 2014), this paper argues that in the context of Philippine presidential democracy, presidential satisfaction shapes the production of political events more than the presence of other issues competing for broadsheet space. Presidents with high presidential approval ratings resort to rhetorical persuasion to insulate their reputation from the delegitimising effects of scandals and crises (Cohen and Hamman 2003). Because of this, the opposition is inclined to be more careful about speaking out against popular presidents in the press to avert criticism and backlash from the president's most ardent supporters. The press, for their part, tends to be conservative in reporting political events when the public mood is generally supportive of the Philippine chief executive.

To test our conjecture, we study how headlines are framed by the Manila Bulletin and the Philippine Daily Inquirer, two of the most widely read broadsheets in the Philippines (The Nielsen Company 2015), from 1992 to 2016. The period covers all presidential administrations after Corazon Aquino: Fidel V. Ramos (1992-1998), Joseph Ejercito Estrada (1998-2001), Gloria Macapagal Arroyo (2001-2010) and Benigno Aquino III (20102016). The study's empirical coverage begins with 1992 as this marks the first national elections under the 1987 Constitution.

We choose the press as the focus of our introspection because even though other forms of mass media receive greater advertisements and exposure, broadsheets still stand as relevant and influential sources of political information in the country. Despite the rise of social media and online news, Filipinos subscribe to traditional media when making political choices and politicians still rely on them for campaigns (Mirandilla 2009). Newspapers have a high diffusion rate of one printed copy for every two persons in Metro Manila, making them as influential as television (Guiogona 2015). It has also been pointed out that television and radio are primarily used for entertainment while newspapers are treated as bases of information (Pertierra 2012). 
Our empirical analysis suggests that the production of media political events is driven by presidential approval ratings, and to some extent, the presence of national elections and the journalistic tradition of the reporting broadsheet. When the president's approval ratings are lower compared to Congress, the president becomes an easier target for the opposition and a much more attractive topic for sensational news by the press. With a smaller circle of supporters of the president, there is also greater likelihood for the opposition and the press to collaborate or collude in the production of political events. In contrast, with little support from the opposition, the press tends to be conservative in the framing and reporting of political events.

This paper proceeds by first examining extant theoretical assumptions on how the press frames political scandals and their relevance to the Philippines. It then expounds on its theoretical contention, drawing from Linz's theory of competing legitimacies in presidential democracies, and explains how political events are created, shared and pirated through mediated forms of communication. This is followed by a discussion of other political and socioeconomic variables which are known to be important in the production of political events by the Philippine press. Afterwards, the paper discusses the motivation behind the case selection, the process that facilitated the collection of data, and the statistical approach for analysis. The paper concludes with a discussion of the findings and their implications for future research.

\section{THE ROLE OF THE PRESS IN THE PRODUCTION OF POLITICAL EVENTS}

Contemporary studies on political scandals digress from the traditional view where media has exclusive monopoly of the framing and production of what is newsworthy. Nyhan $(2014 ; 2017)$, for instance, construes a press collaborating with opposition elites whose assessment whether or not an event is critical determines its subsequent publication as news. This view echoes Entman (2012) who argues that the successful framing of a political event depends on the willingness of the opposition to sponsor the development of the frame, and on the press that relays the message to the public. Early observers such as Ginsberg and Shefter (2002) refer to the strategy by which the opposition expands their network of supporters by tarnishing the image of the incumbent party as "politics by other means." The collaborating press, meanwhile, is rewarded with consumer reach (Thompson 2000) and exclusive beat (Allern and Pollack 2012), driving the press to compete to being the first to come out with the hottest story. 
However, reporting events as political crises is never forthright. Because the press is regarded as the Fourth Estate in most democracies, newspapers must maintain a semblance of independence and objectivity, and hence, be cautious in reporting high profile stories without the concurrence of political elites (Entman 2012). Hearsay can easily ruin a paper's reputation. Without a willing press, however, the political opposition has no venue to expose political crises to the public.

But what makes an event political? Edelman (1964) says events that are politically relevant have both practical and symbolic meanings. Whereas the practical meaning represents what has actually happened, the symbolic facet represents the public's opinion of the event. Political events have practical relevance for inviting attention to a violation of due process (Markovits and Silverstein 1988; Claudio 2014; Rottinghaus 2015), or immoral transgressions of social norms (Nyhan 2014). Distinct from economic crises which are usually characterised by a sudden collapse of markets or the national economy (Henning 2011), political crises involve either a threat to a country's regime (Gonzales 2008), or efforts to weaken government capacity through mobilisation or political violence (Solimano 2005). Nevertheless, the extent of threat or effort is based on normative structures (Solimano 2005) that may vary across countries or time (Entman 2012). What is similar, however, is the reliance on mass media coverage in order to heighten emotions and emphasise the salience that citizens attach to these events (Waisbord 2004; Boomgaarden et al. 2011; Rottinghaus 2015).

Interestingly, most of the aforementioned studies assume a hard-news paradigm typical in the United States (Mindich 1998). In many developing countries, such as the Philippines, journalists are categorised into either those who collaborate with the government or those who see themselves as the people's dissenting voice (Castro 1967; Coronel 2001). The manner by which political elites manipulate the press can also differ from advanced democracies with well-developed party systems. Newspapers in the United States, for instance, can be as partisan as voters and the candidates they support (Alterman 2003; Della Vigna and Kaplan 2007). News coverage, not surprisingly, can be driven by the party orientation of a media outfit's controlling ownership. In the Philippines, however, no partisan ties bind politicians and journalists (Chua and Datinguinoo 1998; Maslog et al. 2015). This implies that coercion and corruption can be used to manipulate information. But this also suggests that Philippine newspapers can produce political events without the support of the opposition. 


\section{PRESIDENT-DRIVEN THEORY OF NEWS FRAMING}

We now expound on this paper's theoretical conjecture, which builds from established assumptions on media-produced political events. We follow Nyhan (2014) and construe media produced political events broadly as encompassing any widespread elite perception of official wrongdoing, impending economic collapse, or political instability, jointly created by the opposition and the press.

Under this definition, a news story must fulfil two criteria before it can be considered a media political event. First, it must be linked to the incumbent president or government. Second, it must be labelled as a "scandal" or a "crisis" in the front-page headlines of mainstream broadsheets. These restrictions are important since, in practice, citizens' reaction to either a scandal or crises arise from mediated information rather than actual experience or observation. While the nation finds itself meeting unfortunate circumstances and mishaps on a daily basis, citizens are rarely capable of coming to terms with these realities until served with elite cues by the mass media (Bennett 1999; Sniderman 1993). In periods of crises, the information gap between the elites and the public widens such that the average citizen is unable to understand complex jargon and processes on their own, and would turn to the interpretation and advice of perceived experts such as economic and political advisers (Carmines and Stimson 1980; Gilens and Murakawa 2002). Crises, therefore, induce information-seeking behaviour among citizens and make them susceptible to the narratives presented by media (Marinova et al. 2018). This is particularly apparent in the Philippines where citizens are at risk because of the lack of social protection (Gonzalez and Manasan 2002), and are already apprehensive of the government (Abinales and Amoroso 2017).

What would mediate media's framing of events into crises?

In a presidential system, both the executive and the legislature can claim to speak on behalf of the people (Linz 1990). This dual legitimacy makes the government susceptible to stalemate and conflict, especially in times of crises. Instead of cooperating with each other, the two branches compete over citizen support and use this as leverage against each other's initiatives.

In the public sphere, however, the president has an inherent advantage. Presidents are not only chief executives but heads of state and their symbolic prerogatives can expectedly dominate day-to-day news coverage and are at the centre of public spotlight (Gilbert 1989; Eshbaugh-Soha 2013; Marshall 2008). This can endow the presidency with immediate advantages in any political confrontation. Yet this also exposes the office to media sensationalism and degrades the president into a caricature instead of a political leader (Gilbert 
1989; O'Donnell 1994). Without a strong support base, the president is easily blamed for every scandal or crisis.

However, politicians with high approval ratings receive preferential treatment from their colleagues and attract positive coverage by the press (Chua 2004; Hedman 2010). Consistent with the popularity-context hypothesis, popular presidents are able to effectively insulate themselves from the delegitimising effect of political events through rhetoric (Cohen and Hamman 2003). Presidents who enjoy wide public satisfaction can also claim high political legitimacy. When they speak, they are regarded as representing the interest of citizens. They are also construed as credible sources of information. This public legitimacy creates a dissuading effect on the political opposition and a persuasive effect on the press. Conversely, when the presidency suffers from low legitimacy amidst coordinate and coequal institutions, the persuasive power of the president dwindles. Being a more credible source of information than the president, the opposition could easily turn policy mishaps into allegations of incompetence or corruption against the president. The press, in turn, is more likely to frame unfortunate circumstances into political events and attribute them to government.

The process of framing stories into political events also has a reinforcing effect on the already asymmetric informational relationship between citizens and elites. For instance, citizens are known to develop counterarguments against news that challenge their beliefs (disconfirmation bias) (Taber and Lodge 2006), seek only information that serves to confirm their preconceived beliefs (confirmation bias) (Iyengar and Hanh 2009; Jerit and Barabas 2012), or filter only those that strengthen what they already know (prior-attitude effect). If citizens strongly support the president, they are likely to dismiss how news reports portray political events. At the same time, ardent supporters of the president can criticise the sources of these news reports as resorting to cheap political tactics. The press and the opposition would then be dissuaded from reporting negatively about the president. On the other hand, citizens who doubt the president's political legitimacy are more likely to blame the president for every scandal or crisis that unfolds.

This now brings us to our main hypothesis:

$\mathrm{H}_{1}$ : The press is likely to generate a media political event if the president's public approval is lower relative to other institutions, particularly, Congress. 


\section{OTHER POLITICAL AND SOCIOECONOMIC DETERMINANTS OF POLITICAL EVENTS}

We also account for other variables which are known in the literature to induce the production of political events by media. These variables include:

\section{News Congestion}

Short-term economic interests can easily trump a news network's long-term and subjective ideological orientations (Kellner 1981). In the Philippines, for instance, media networks face immense pressure to popularise content and end up sensationalising news reports (Coronel 2010). Even in otherwise technical topics such as agricultural biotechnology, the ability of Philippine newspapers to garner sufficient interest depends on their ability to infuse emotion and controversy into the narratives (Navarro et al. 2011; International Service for the Acquisition of Agri-biotech Applications [ISAAA] 2017; Nidoy and Manalo 2018). Since news articles are influenced by the pressure to appeal to audience, journalists prioritise news stories that have immediate and high audience demand (Hamilton 2004). Extant studies using qualitative data (Eisensee and Stromberg 2007; Robinson 2007) demonstrate that important news stories compete with media events in shifting public attention and generating demand for news coverage.

In this study, however, for news to be considered as inducing congestion, it must satisfy two conditions. First, it must be exogenous to presidential approval and political events. As such, news congestion does not include stories about the government and the national economy. Second, they must be salient enough to generate audience demand on their own. Following Newman and Forcehimes' (2010) criteria, a news is salient if it appears in the front page of mainstream newspapers at least three times in a month. When a story dominates public discussions, journalists are compelled to follow the trend and give the audience what they want. Meanwhile, members of the opposition would likely save their allegations for another day when the heat of the competing news dissipates. Thus, we hypothesise that:

$\mathrm{H}_{2}$ : News congestion decreases the likelihood of production of a media political event. 


\section{Elections}

Elections in delegative democracies are highly emotional events (Gonzales 2014). Elections are treated as a zero-sum game for political power among the elites. Elections give those who win them the prerogative to run the country according to their preference (O'Donnell 1994). It is well known that a scandal or crisis can affect the outcome of elections (Hernandez and Kriesi 2016; Pereira and Waterbury 2018). However, their relevance in the public eye faces a "cascade" wherein interest in the media political event decreases over time (Entman 2012). Thus, members of the opposition are incentivised to produce more political events that challenge the authority of incumbents and compromise their standing in the public eye during election periods. Members of the press, on the other hand, capitalise on the heightened interest in political information during election periods by producing sensational political events. Thus, we expect:

$\mathrm{H}_{3}$ : The likelihood of producing a media political event increases during election periods.

\section{Broadsheet Type}

The study also accounts for the two dominant cultures that define journalism in the Philippines. The Manila Bulletin and the Philippine Daily Inquirer proceed from two divergent journalistic traditions. While the Manila Bulletin is known to be conservative on its views against the government (Seraca 2018), the Philippine Daily Inquirer takes pride in its being part of the dissenting press, and has no qualms about sourcing information from civil society groups and opposition elites (CMFR 2005). Hence, we expect:

$\mathrm{H}_{4}$ : Members of the dissenting press, such as the Philippine Daily Inquirer, are more likely to report a political event.

\section{Presidential Party in Congress}

Finally, we control for the president's dominance in the Philippine Congress. If the majority of the members of the Senate and the House of Representatives is made up of members of the same party as the president, allegations of scandals and crises are expected to be less frequent. Unlike the two-party system in the United States, Philippine political parties are clientelist networks formed for elections and patronage (Lande 1965). 
Despite the weakness of political parties in the country, the president's party members may still be incentivised to preserve the president's position to secure their source of patronage and political machinery. When they dominate Congress, the president's party members suppress investigations on misconduct. Conversely, probes about the president are much more intense in times of divided government (Parker and Dull 2009). When the president's party has no control over the legislature, the opposition can easily launch investigations on scandals and generate more information on the event for the press. Thus:

$\mathrm{H}_{5}$ : The press is less likely to report a media political event when the president enjoys a majority in Congress.

We also include fixed effects for presidential administrations in all models to account for latent characteristics that may have influenced their relationship with the press. Studies suggest, for instance, that female politicians are judged much more harshly during corruption allegations (Reyes-Housholder 2019) and sexual scandals (Żemojtel-Piotrowska et al. 2016) than their male counterparts. The personality and leadership style of presidents have also been shown to affect their ability to manage crisis periods and maintain public confidence (Hart et al. 2009; Boin et al. 2010).

\section{DATA AND METHOD}

News data for this study were sourced primarily from the Manila Bulletin and the Philippine Daily Inquirer since these are two of the most widely read broadsheets in the Philippines (The Nielsen Company 2015) and are known to index elite opinion as part of the mainstream press. The two broadsheets can also be construed to represent the dominant journalistic traditions in the Philippines. While admittedly other forms of mass media receive greater advertisements and exposure, the study is limited to newspapers as they remain to be among the most influential political media in the country. Television and radio may enjoy greater subscription yet the role they serve the Filipino public is still largely confined to entertainment. On the other hand, print newspapers have become established sources of political information (Pertierra 2012). Despite the rise of social networking sites and online news in the country, both citizens and politicians still resort to traditional media to guide political choices (Mirandilla 2009). 
This study also limits its coverage to the period from 1992 to 2016. This period spans the administrations of Fidel V. Ramos (1992-1998), Joseph Ejercito Estrada (1998-2001), Gloria Macapagal Arroyo (2001-2010) and Benigno Aquino III (2010-2016). The coverage begins with Ramos' victory in the 1992 elections since this event marks the first national elections in the country under the 1987 Constitution. Elections create political legitimacy in precarious democracies. Such legitimacy is important for Philippine presidents who are regarded as custodians of the national interest (O'Donnell 1994). The study does not include news coverage of events during the current administration (Duterte).

Constructed week sampling was employed in the selection of newspaper data in order to maximise efficiency and to control for cyclical biases in weekly news patterns. This type of stratified random sampling is known to produce a sample that is able to represent the characteristics of newspapers in all days of the week (Luke and Caburnay 2011). In our constructed week sampling approach, all Mondays were identified. A Monday is randomly selected from this set of days. This process is then repeated for all days of the week. Although one constructed week can already represent a six-month period, this could miss important short-term events (Riffe et al. 1993; 2006; Hester and Dougall 2007). To account for the short-term events, we rely on two constructed weeks as representing a quarter (three months) worth of news headlines.

For a news story to be considered a salient political event, it must have been labelled as crisis or scandal by the broadsheet. Specifically, we used the words "scandal," "crisis," "controversy" and "scam" as keywords and counted them in the sampled headlines. Our coding follows Perez-Linan (2007) and treats as scandal "news events disclosing episodes of corruption, immorality, or abuse of power" (Perez-Linan 2007: p. 93). These include reports of abuse of power, corruption allegations and attacks on the character of the president. Crisis, on the other hand, can be economic or political. An economic crisis includes reports on the state of the Philippine economy, while a political crisis encompasses those who discuss the state of the Philippine government or the quality of the country's democracy. From the categorised headlines, those that do not concern the incumbent president or administration were removed. Based on the data, the two newspapers report as much as five media political events in a month.

We then estimated logistic regression models in which the variable of interest is the probability of having at least one news report pertaining to a crisis or scandal in a given month. 
For the main independent variable, we follow Panao (2019) and construe presidential approval as the proportion of the net satisfaction of the president to that of Congress. This is done by dividing the net satisfaction rating of the president by the net satisfaction rating of the legislature. Because we treat the Senate and the House of Representatives as one institution, we took the average of their net satisfaction ratings as a measure of the legislature's. Net approval ratings are all based on the quarterly surveys of the Social Weather Stations (SWS). The net approval rating ranges from -100 to +100 . The figures are interpolated to get monthly observations, then lagged by a month to reduce the possibility of endogeneity between the media political event and presidential approval.

News congestion, on the other hand, is the discrete number of events that compete with media political events for audience attention and demand. These are events that are salient for the majority of citizens but exogenous to politics. We follow Newman and Forcehimes (2010) and consider a topic as important in public discourse if it has appeared in the front pages of a newspaper at least three times in a given month, but has nothing to do with politics, the economy, or the social issues of the country. The number of events is then aggregated to produce monthly observations.

Presidential administration is operationalised as a dichotomous categorical variable coded " 1 " for the period covering the presidency of Fidel V. Ramos, "2" for Joseph Estrada, "3" for Gloria Macapagal Arroyo and "4" for Benigno Simeon Aquino III.

Election is a dichotomous categorical variable coded 1 if a news appeared during an election year and 0 if otherwise.

Broadsheet is a categorical variable coded 1 if the headline was taken from the Philippine Daily Inquirer, and 2 if it was from the Manila Bulletin.

Finally, presidential party in Congress is a continuous variable corresponding to the percentage share of members of the Senate and the House of Representatives who belong to the incumbent president's political party. This is obtained by dividing the number of members who belong to the party of the incumbent president by the total number of members of the Senate or the House of Representatives.

\section{RESULTS AND DISCUSSION}

Table 1 gives a descriptive summary of the main variables of interest. Constructed week sampling yielded 24,483 headlines, of which 5,277 were classified as media political events and 4,520 are categorised as news 
congestion. News congestion events range from natural calamities (Mt. Pinatubo eruption in 1992 and typhoon Yolanda in 2014) and accidents (Ozone fire incident in 1996 and the Wowowee stampede in 2006) to celebrity deaths (Pope John Paul II in 2005 and Whitney Houston in 2012). Among post-EDSA presidents, Arroyo had the lowest and the highest PresidentCongress approval ratio. Ramos had the fewest party allies in the Senate and the House of Representatives with just 10.28 percent. Meanwhile, with 44.64 percent, Estrada had the most party allies. While not exactly a majority, Estrada's political party, Laban ng Makabayang Masang Pilipino (LAMMP), had majority leverage in Congress due to its coalition with the Liberal Party. This coalition is widely believed to have blocked the initial impeachment complaints against Estrada (Kasuya 2005).

Table 1: Descriptive summary of variables.

\begin{tabular}{lccccc}
\hline Variable & Obs & Mean & Std. dev. & Min & Max \\
\hline $\begin{array}{l}\text { Dependent variables } \\
\text { Media political event }\end{array}$ & 584 & 0.267 & 0.595 & 0 & 1 \\
$\begin{array}{l}\text { Independent variables } \\
\text { Presidential approval }\end{array}$ & 584 & 29.167 & 11.711 & -53 & 69 \\
Presidential approval ratio & 583 & 1.013 & 2.429 & -19.167 & 31.618 \\
Control variables & & & & & \\
News congestion & 584 & 0.2671233 & 0.5949023 & 0 & 5 \\
Administration & 584 & 3.584 & 1.159 & 1 & 4 \\
Election year & 584 & 0.164 & 0.371 & 0 & 1 \\
Type of broadsheet & 584 & 1.5 & 0.500 & 1 & 2 \\
Presidential party in Senate & 584 & 29.17337 & 11.74319 & 10.28 & 44.64 \\
\hline
\end{tabular}

Sources: The Manila Bulletin, the Philippine Daily Inquirer and the Social Weather Stations

To illustrate the variety of media political events observed, we follow PerezLinan's (2007) typology of scandals in Latin American democracies, and defined them as "news events disclosing episodes of corruption, immorality, or abuse of power" (p. 93). Figure 1 shows that corruption allegations comprise the majority of media political events in the country. As politicians battle for public trust in the Philippines, their rhetoric of good governance and democracy is often accompanied by accusations of corruption against their opponents (Case 2003; Jaca 2016). While the production of character assassination is relatively similar between both broadsheets, the Philippine Daily Inquirer is much more critical of the abuse of power by the president. 
This is in line with the Philippine Daily Inquirer's perceived role as a critic of the government. In conjunction, news reports of perceived threats to democracy, calls for constitutional reform, episodes of economic collapse, and the unstable power supply in the country, have also been observed.

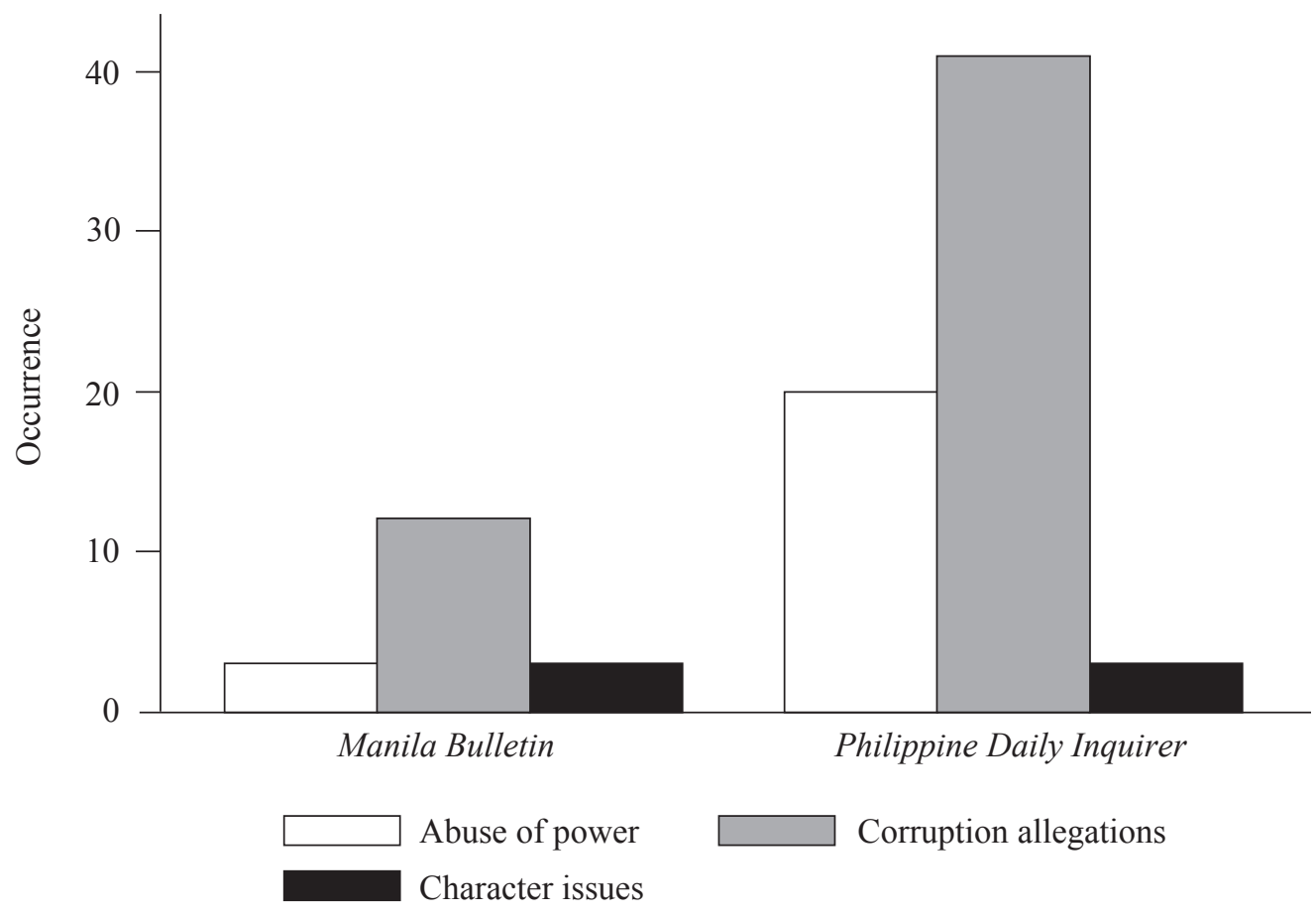

Figure 1: Bar graph of scandals.

Even though scholars suggest that the type of event can influence how the public reacts (Basinger 2013), all political events depend on the media for coverage and are all equally delegitimising to the president. In this study, we treat all types as falling under our conceptualisation of media political event. Each presidential administration faced six media political events per year on average. However, media political events seemed to have increased distinctively during Arroyo's term. Some scholars attribute this to the developments in communication technology and investigative journalism (Garrard and Newell 2006). There are as well those who construe this as evidence of the public's declining trust on the integrity of political competition (Bennett 1999; Davis 2006).

Table 2 shows four models that test the hypotheses of the study. The first model tests for the effect of presidential approval on the production of media political events while the second model tests for the effect of the President-Congress approval ratio. 
Table 2: Determinants of the production of media political events.

\begin{tabular}{|c|c|c|c|c|}
\hline & $\begin{array}{l}\text { (1) } \\
\text { Media political } \\
\text { event }\end{array}$ & $\begin{array}{l}\text { (2) } \\
\text { Media political } \\
\text { event }\end{array}$ & $\begin{array}{c}\text { Media political } \\
\text { event }\end{array}$ & $\begin{array}{c}\text { (4) } \\
\text { Media political } \\
\text { event }\end{array}$ \\
\hline Presidential approval & $\begin{array}{l}-0.00135 \\
(0.00326)\end{array}$ & & & \\
\hline $\begin{array}{l}\text { Lagged presidential } \\
\text { approval ratio }\end{array}$ & & $\begin{array}{l}-0.0971^{*} \\
(0.0477)\end{array}$ & & $\begin{array}{l}-0.240^{* *} \\
(0.0863)\end{array}$ \\
\hline News congestion & & & $\begin{array}{c}-0.0227 \\
(0.05)\end{array}$ & $\begin{array}{c}-0.022 \\
(0.0497)\end{array}$ \\
\hline Ramos administration & & & $\begin{array}{c}1.045 \\
(1.122)\end{array}$ & $\begin{array}{l}-0.143 \\
(1.206)\end{array}$ \\
\hline Estrada administration & & & $\begin{array}{c}1.811 \\
(1.117)\end{array}$ & $\begin{array}{c}0.601 \\
(1.198)\end{array}$ \\
\hline Arroyo administration & & & $\begin{array}{c}1.179 \\
(1.107)\end{array}$ & $\begin{array}{l}-0.609 \\
(1.278)\end{array}$ \\
\hline Aquino III administration & & & $\begin{array}{c}1.629 \\
(1.126)\end{array}$ & $\begin{array}{c}0.297 \\
(1.220)\end{array}$ \\
\hline Election year & & & $\begin{array}{l}0.704^{* *} \\
(0.273)\end{array}$ & $\begin{array}{l}0.812^{* *} \\
(0.278)\end{array}$ \\
\hline Philippine Daily Inquirer & & & $\begin{array}{l}0.863^{* * *} \\
(0.217)\end{array}$ & $\begin{array}{l}0.852^{* * *} \\
(0.219)\end{array}$ \\
\hline Presidential party in Congress & & & $\begin{array}{c}0.0173 \\
(0.0105)\end{array}$ & $\begin{array}{c}0.0215 \\
(0.0108)\end{array}$ \\
\hline Constant & $\begin{array}{c}-1.313^{* * *} \\
(0.122)\end{array}$ & $\begin{array}{c}-1.256^{* * *} \\
(0.109)\end{array}$ & $\begin{array}{c}-3.777^{* * *} \\
(1.104)\end{array}$ & $\begin{array}{l}-2.272 \\
(1.223)\end{array}$ \\
\hline $\mathrm{N}$ & 584 & 583 & 584 & 583 \\
\hline
\end{tabular}

Note: Standard errors in parentheses; ${ }^{*} p<0.05 ;{ }^{* *} p<0.01$; ${ }^{* * *} p<0.001$

The estimates in Table 2 confirm our hypothesis that presidential popularity amidst competing institutions drives news production of media political events. Model 1 suggests that presidential approval ratings per se do not seem to have an impact on the production of scandals and crises. Yet when presidential approval is construed in relation to the approval ratings of another institution, particularly Congress, it becomes very significant in shaping the attention of the press towards political events (Model 2). This implies that the executive and the legislature's competing claims to legitimacy affect not only the vulnerability of the president to political attacks but also how citizens react to media political events. Figure 2 illustrates this through a predicted margins plot showing the probability of a media political event to occur based on presidential approval. The figure indicates that the probability of a scandal 
or a crisis to be reported in a given month starts to exponentially increase as the presidential approval ratio decreases. When presidential approval ratio is at -10 , media political events is predicted to increase to 74 percent. This coverage increases to 97 percent as presidential approval ratio drops to -20 critical of the president.

Adjusted predictions with 95\% CIs

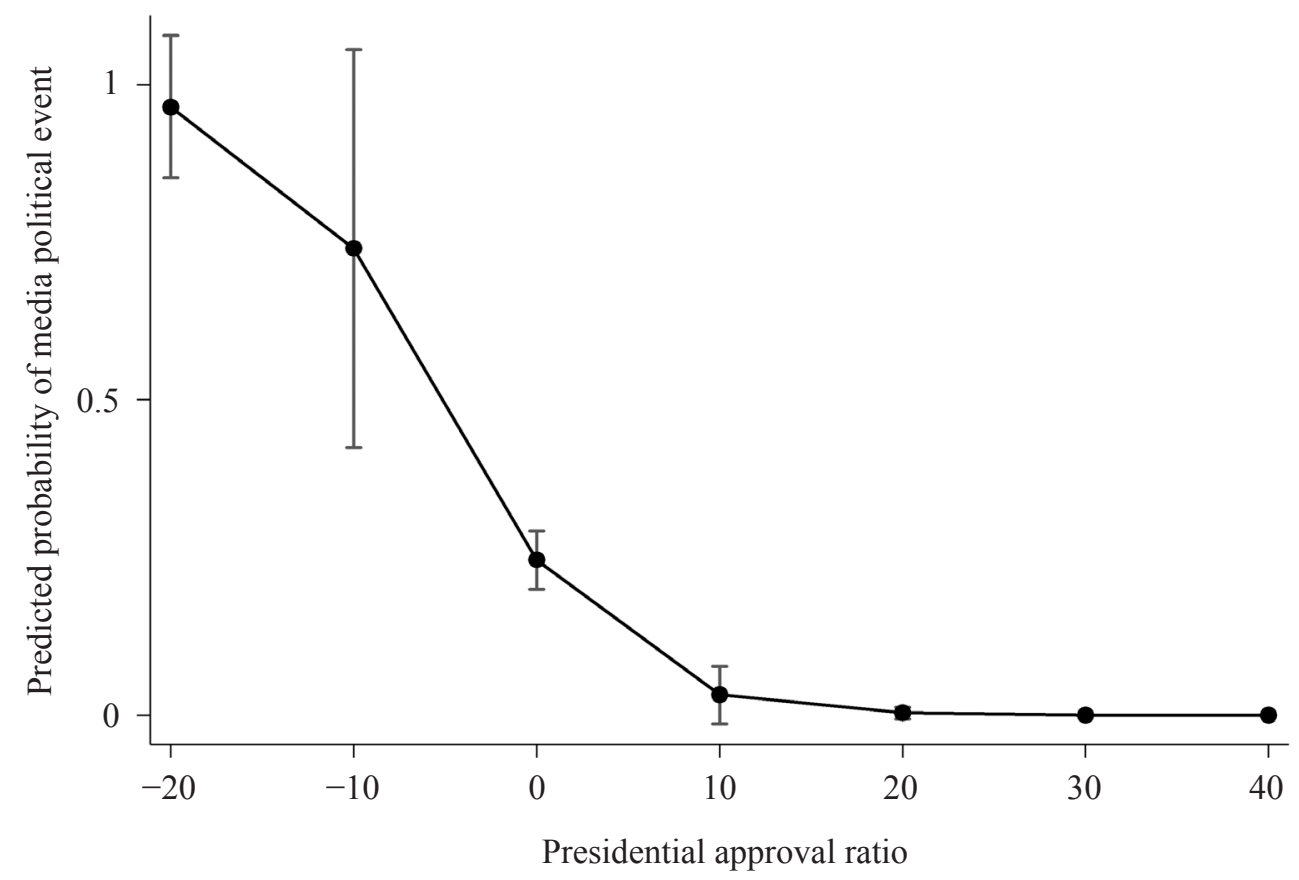

Figure 2: Predictive margins plot for presidential approval ratio.

These estimates suggest that scandals and crises are more attractive to produce when the president is less popular than Congress. Presidential approval, on its own, is not enough. We must also take into consideration the competition between the executive and the legislature over public prestige. In this case, public approval becomes an important resource for politicians. The institution that is more favoured by the public has greater credibility and can be absolved of government failures. When the president is less popular than the Congress, citizens disregard the president as a source of information and as a representation of their interests, and turn to the opposition as a reliable and authoritative reference. This emboldens the opposition to be more critical of the incumbent administration and to publicise their allegations against it. Moreover, citizens are more receptive to these media political events. Thus, the publishing press is encouraged to frame reports as scandals or crises to ride on public sentiment and enhance their reputation. 
Model 3 tests for the effects of control variables: presidential administration, national elections, the type of broadsheet and the presidential party's dominance in Congress. Model 4 is a fully specified model with presidential approval ratio and the aforementioned control variables known in the literature to explain press coverage. All models have been estimated using logistic regression.

The results suggest that presidential parties and news congestion have no significant bearing on the production of media political events. This only adds support to what seems to be already established about political parties in the Philippines. Parties in the Philippines are known to exist with only elections in mind and conspicuously lack the ideological foundations to bind politicians programmatically once in power (Lande 1965). Party membership does not appear as significant in the production of media political events because of the inherent weakness of the Philippine party system. Instead, presidents in office often rely on patronage and their public image to influence legislators (Kasuya 2003; Thompson 2014).

News congestion likewise does not seem to predict the production of media political events. This contradicts the slow news hypothesis espoused in previous studies which states that the profit-driven nature of journalists would drive the press to prioritise news reports that sell easily (Nyhan 2014). In countries such as the United States, studies imply that high audience demand could crowd out potential media political events. In the Philippines, however, there appears to be no evidence supporting this. It must be mentioned, however, that unlike their counterparts in the United States, Philippine journalists are underpaid, are exposed to a lot of risks, and are much more susceptible to bribery and corruption (Chua and Datinguinoo 1998). However, Philippine journalists also stand out for their risk-taking nature and their coverage of monumental political events, such as the so-called "Juetenggate" scandal which forced Estrada to resign (Coronel 2001; Ables 2003). As such, it can be implied that journalists in the country do not just take into account the marketability of news but also the political and economic implications of the story.

National elections and the type of broadsheet are also found to significantly affect the production of media political events. Figures 3 and 4 illustrate the relationship through predictive margins plots. Holding all other variables constant at their means, the production of media political events is 129 percent more likely to occur during election years. This suggests that timing also matters. When the ratio of presidential approval to Congress approval drops to -10 , there is an 84 percent probability of 
media political events to be produced during election years, whereas there is only a probability of 72 percent when there are no elections. Because of the high stakes associated with winning national elections (O'Donnell 1994), the opposition is perhaps stockpiling scandal or crisis allegations and strategically spill them out or revive them when elections draw near. Unlike the president, members of Congress are incentivised by the prospects of re-elections. Because of high competition for publicity during elections, they could draw attention to the shortcomings of the incumbent administration to gain public attention. For example, news reports on new information regarding the Hello Garci scandal on June 2005, and the National Broadband Network-ZTE (NBN-ZTE) scam on October 2007, both of which took place during Arroyo's presidency, surfaced during the 2010 elections even though these scandals took place years earlier. Election periods also bring with them a heightened interest in political information among citizens which can incentivise the press to publish more political events.

Adjusted predictions of election years with 95\% CIs

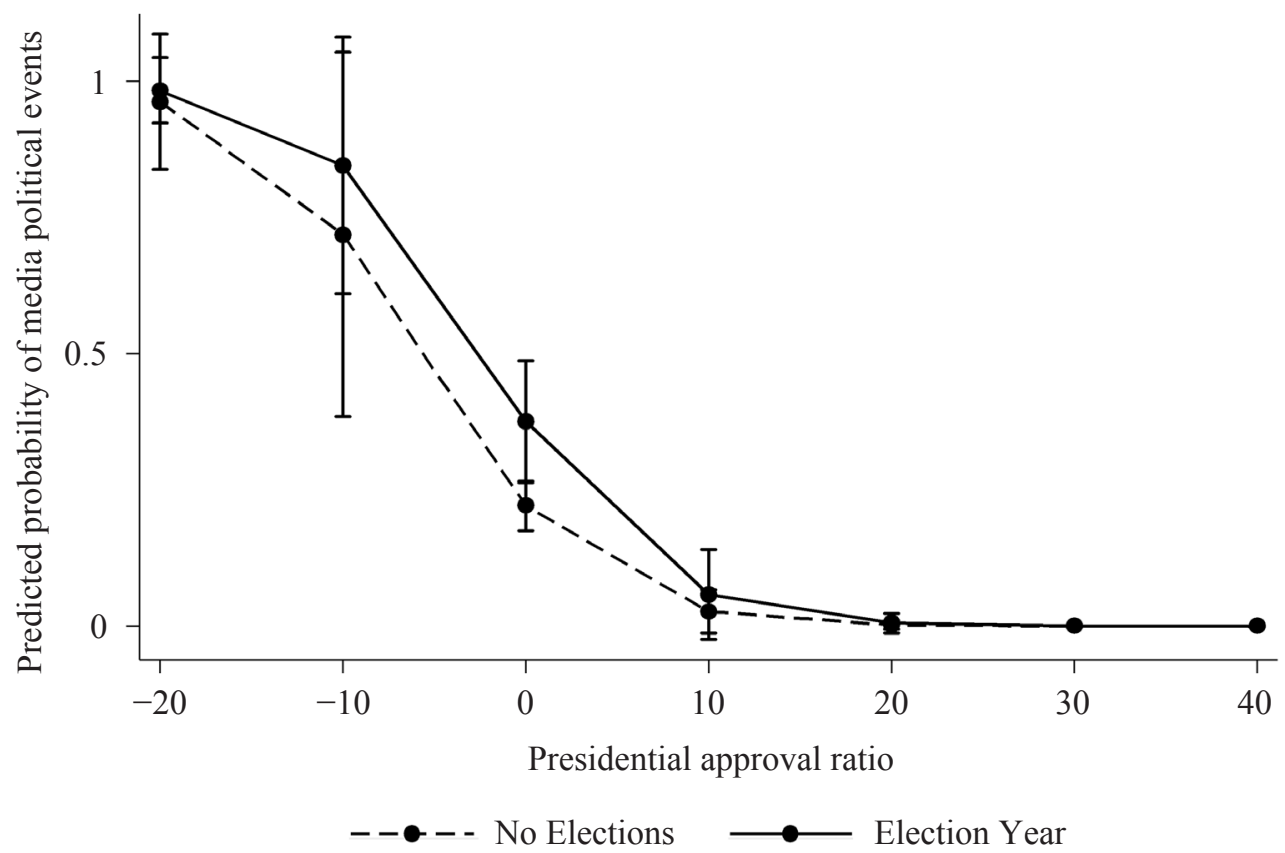

Figure 3: Predictive margins plot for election year.

The editorial tenets of broadsheets also appear to matter in the production of media political events. Holding all other variables at their means, the Philippine Daily Inquirer seems 134 percent more likely to produce media political events than the Manila Bulletin. When the ratio of presidential approval to Congress approval falls to -10 , there is an 81 percent probability for the Philippine 
Daily Inquirer to cover a media political event. For the Manila Bulletin however, the probability is just 66 percent, which is conspicuously lower. The Philippine Daily Inquirer which identifies itself as part of the dissenting press has a higher rate of publishing media political events compared to the Manila Bulletin which is regarded as more accommodating of the government. The sources newspapers rely on in reporting media political events possibly also shape news coverage. The Manila Bulletin, for instance, is known to privilege the view of government officials and incumbent politicians who tend to be more optimistic and conservative in their treatment of media political events. The Philippine Daily Inquirer, on the other hand, is known to widen its discourse to include civil society groups and alternative sources of public opinion (Nidoy and Manalo 2018; ISAAA 2017). Both traditions play a role in stabilising and strengthening democratic institutions.

Adjusted predictions of broadsheet with $95 \%$ CIs

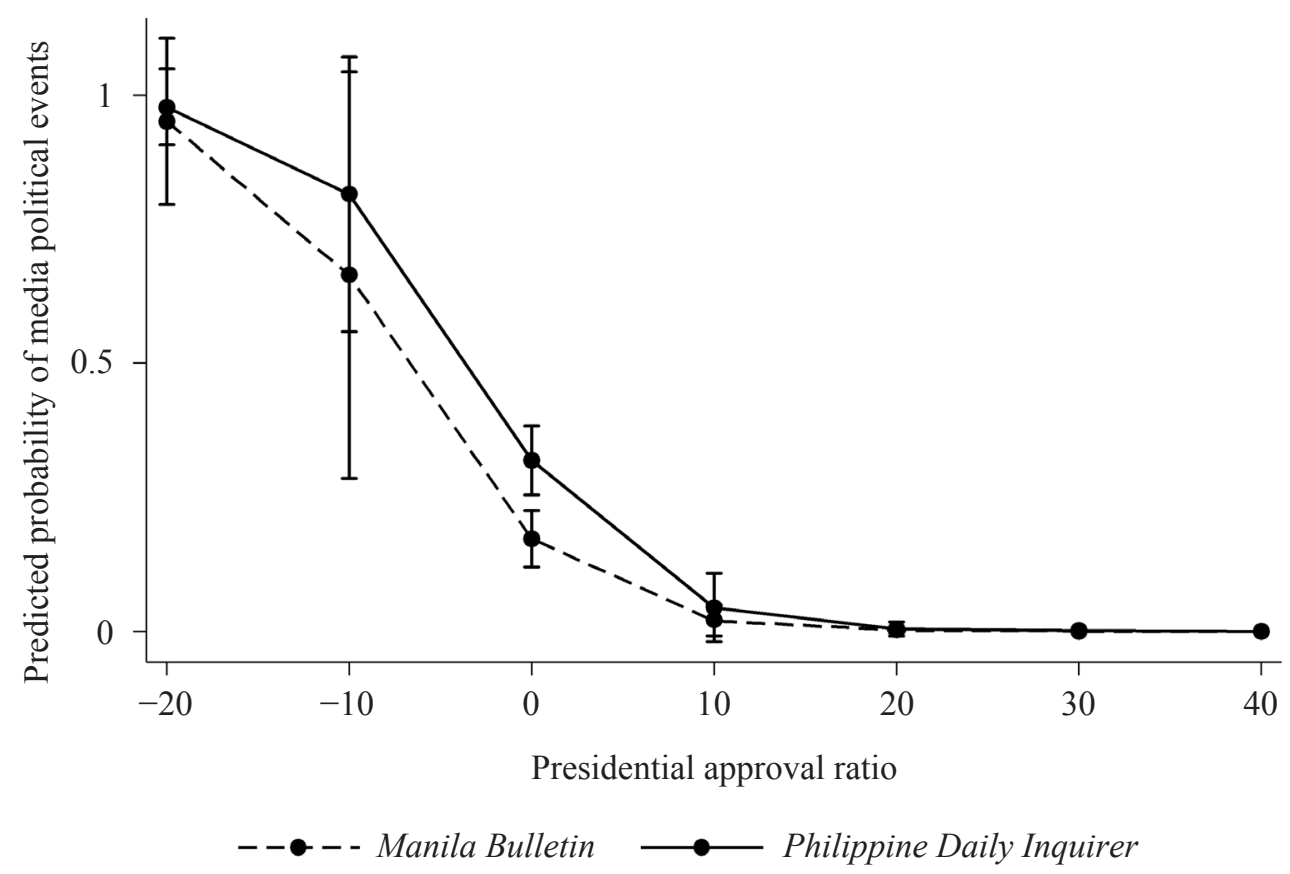

Figure 4: Predictive margins plot for broadsheet.

\section{CONCLUSION}

Do the president's public approval ratings, amidst competing coordinate institutions, shape how political events are reported by the press? Framed as the centre of national power, the president is an easy target for blame by the press when political mishaps take place. Ideally, this should foster democratic 
accountability by keeping citizens informed and keeping the president disciplined. In contrast, this study argues that media coverage of political events is not as consistent as it is assumed to be. Because the opposition and the press have their own interests in mind, news reports regarding government misconduct are strategically released for their benefit.

In this study, we examine how competing claims to legitimacy in the Philippines influence the propensity of the Philippine Daily Inquirer and the Manila Bulletin to report on political scandals or crises from 1992 to 2016. Drawing from Nyhan (2014; 2017), we posit that scandals and crises are created and publicised through cooperation between the press and the opposition. We argue that media political events are produced when the president is less popular than competing institutions. When presidents are less popular than Congress, in particular, they become an easy target for the opposition and a much more attractive topic for sensational news. With a much smaller circle of supporters for the president, there is also a smaller risk involved in reporting political scandals and crises. Using logistic regression models, we find that the ratio of presidential approval to that of Congress, the presence of national elections, and the journalistic tradition of the broadsheet can influence the production of media political events.

Needless to say, the political context of the country plays an important role in how journalists choose to frame their news reports. Our empirical introspection of newspaper headlines suggests that the Philippine press, despite being recognised as a watchdog of the government, remains susceptible to the mood of the general public. Because of this, popular presidents are insulated from delegitimising news while unpopular ones are vulnerable to negative reports. Public approval ratings then do not just aid politicians in bargaining for policy concessions but also facilitates the exercise of politics by other means. As the investigation of political events becomes a new arena of political competition, high approval ratings give politicians the credibility to both undermine allegations against them and reveal the misconduct of their opponents. Because of this, the opposition's willingness to challenge incumbents is contingent on their popularity. Moreover, citizens are much more receptive of criticism towards an already unpopular president. This, along with the availability of support and information from the opposition, incentivises the press to publish political scandals against unpopular presidents. In the end, unpopular presidents are under constant scrutiny from the press and the opposition while popular ones, regardless of their transgressions, are rarely held accountable for their actions. 
Be that as it may, we acknowledge this study's limitations. The reliance on headlines instead of the entire text of news reports limits the scope of the analysis to a very small part of the journalist's voice. To improve the validity of the study, future research may want to account for the journalist's use of controversial language, among other things, which can be accomplished through textual analysis. This study can also be extended to include an examination of the success of political events in generating audience demand over time. An interesting phenomenon in the study of political events is the so-called "cascade," which indicates how long an event has relevantly preoccupied public discourse (Entman 2012). After all, the success of the production of a media political event is measured not just by its tendency to appear in the front pages but also in its tenacity to stay in the spotlight for a considerable amount of time. Finally, further introspection into the separate roles of the Senate and the House of Representatives in the politics by other means should be studied further. By treating the chambers as one institution, this study was unable to acknowledge the relative independence of the Senate compared to the House of Representatives. Members of the House of Representatives are mainly concerned about consolidating power in their local bailiwicks and may be more amenable to support the president in exchange for pork-barrel distributions, while Senators have re-election incentives in pushing for investigations into mishaps (Kawanaka 2010).

As an implication, our findings call for a re-examination of the media's role as a watchdog in Philippine democracy. Because of commercial and political pressures, media may not necessarily be leading in the formation of public opinion, as previous studies suggest, but merely reinforcing and institutionalising the prevailing mood of the citizenry. To become true pillars of democracy, the press in the Philippines should exercise vigilance regardless of how the public views the president. It must also strive to improve investigative journalism instead of relying solely on the opposition for political information. Finally, there must be economic and political safeguards to motivate independent and truthful reporting in the country.

\section{ACKNOWLEDGEMENTS}

No financial grant was received in the preparation of this manuscript. The authors thank two anonymous reviewers for their insightful comments. 


\section{NOTES}

* Gabrielle Ann S. Mendoza is a student of the Bachelor of Arts Master of Arts (BAMA) Political Science Honours programme at the University of the Philippines Diliman. Her current research looks at how presidential popularity influences the magnitude and sentiment of news stories on presidents in the post-EDSA Philippines. A very early version of this paper, and the dataset from which estimates were based, were submitted as part of course requirements in the Social Sciences 203 (Advanced Statistics for the Social Sciences) class supervised by Dr. Rogelio Alicor L. Panao.

** Rogelio Alicor L. Panao, PhD, is Associate Professor of Political Science at the Department of Political Science, University of the Philippines Diliman. The data and operational measure for competing legitimacy were adapted from the paper, Competing Legitimacy, Legitimated Control: Public Approval and Presidential Ordinance Power in the Philippines, 1987 to 2016, presented at the 2019 Wenzao International Conference on Southeast Asian Studies in Kaohsiung, Taiwan.

\section{REFERENCES}

Abinales, P. N. and Amoroso, D. J. 2017. State and society in the Philippines. Lanham: Rowman and Littlefield.

Ables, H. A. 2003. Mass communication and Philippine society. Quezon City: University of the Philippines Press.

Allern, S. and Pollack, E. 2012. Scandalous! The mediated construction of political scandals in four Nordic countries. Gothenburg: Nordicom.

Alterman, E. 2003. What liberal media? The truth about bias and the news. New York: Basic Books.

Basinger, S. J. 2013. Scandals and Congressional elections in the post-Watergate era. Political Research Quarterly 66 (2): 385-398. https://doi.org/10.1177 \%2F1065912912451144

Bennett, W. J. 1999. The death of outrage: Bill Clinton and the assault on American ideals. New York: Free Press.

Boin, A. et al. 2010. Leadership style, crisis response and blame management: The case of Hurricane Katrina. Public Administration 88: 706-723. https://doi.org/10.1111/ j.1467-9299.2010.01836.x

Boomgaarden, H. G., de Vreese, C. H. and van Spanje, J. 2011. Covering the crisis: Media coverage of the economic crisis and citizens' economic expectations. Acta Politica 46: 353-379. https://doi.org/10.1057/AP.2011.18

Carmines, E. G. and Stimson, J. A. 1980. The two faces of issue voting. American Political Science Review 74: 78-91. https://doi.org/10.2307/1955648

Case, W. 2003. Politics in Southeast Asia: Democracy or less. London: Routledge Curzon.

Castro, J. L. 1967. Press. In Philippine mass media in perspective, eds. Feliciano, G. D. and Icban, C. J. Jr., 3-15. Quezon City: Capitol Publishing House.

CMFR. 2005. Philippines: Freedom of expression and the media. https://www.article19. org/data/files/pdfs/publications/philippines-baseline-study.pdf. 
Chua, Y. T. 2004. Much ado about numbers. Philippine Center for Investigative Journalism: iReport (January-June).

Chua, Y. and Datinguinoo, V. 1998. The media as marketplace. In News for sale: The corruption of the Philippine media, ed., Hofileña, C. F., 90-109. Quezon City: Philippine Centre for Investigative Journalism.

Claudio, L. E. 2014. From scandalous politics to public scandal: Corruption, media, and the collapse of the Estrada regime in the Philippines. Asian Politics and Policy 6 (4): 539-554. https://doi.org/10.1111/aspp. 12138

Cohen, J. E. and Hamman, J. A. 2003. The polls: Can presidential rhetoric affect the public's economic perceptions? Presidential Studies Quarterly 33 (2): 408-422. https://doi.org/10.1111/j.1741-5705.2003.tb00037.x

Coronel, S. 2001. The media, the market and democracy: The case of the Philippines. Javnost - The Public 8 (2): 109-126. https://doi.org/10.1080/13183222.2001 .11008774

2010. Corruption and the watchdog role of the news media. In Public sentinel: News media and governance reform, ed. Norris, P., 111-136. Washington, DC: The International Bank for Reconstruction and Development.

Davis, L. J. 2006. Scandal: How "gotcha" politics is destroying America. New York: Palgrave Macmillan.

De Neve, J-E. et al. 2018. The asymmetric experience of positive and negative economic growth: Global evidence using subjective well-being data. The Review of Economics and Statistics 100 (2): 362-375. https://doi.org/10.1162/REST_a_00697

Della Vigna, S. and Kaplan, E. 2007. The Fox News effect: Media bias and voting. Quarterly Journal of Economics 22: 1187-1234. https://doi.org/10.3386/w12169

Dixon, M. 2018. Economic crisis and mass protest: The Pots and Pans Revolution in Iceland. Social Forces 96 (4): 1-3. https://doi.org/10.1093/sf/soy029

Edelman, M. 1964. The symbolic uses of politics. Champaign: University of Illinois Press. 1988. Constructing the political spectacle. Chicago: University of Chicago Press.

Eisensee, T. and Stromberg, D. 2007. News droughts, news floods, and U.S. disaster relief. The Quarterly Journal of Economics 122 (2): 693-728. https://doi.org/10.1162/ qjec.122.2.693

Entman, R. 2012. Scandal and silence: Media responses to presidential misconduct. Malden, MA: Polity.

Eshbaugh-Soha, M. 2013. Presidential influence of the news media: The case of the press conference. Political Communication 30 (4): 548-564. https://doi.org/10.1080/ 10584609.2012.737438

Garrard, J. and Newell, J. L. 2006. Scandals in past and contemporary politics. Manchester: Manchester University Press.

Gilbert, R. E. 1989. President versus Congress: The struggle for public attention. Congress and the Presidency 16 (2): 83-102. https://doi.org/10.1080/07343468909507926

Gilens, M. and Murakawa, M. 2002. Elite cues and political decision-making. In Research in micropolitics: Political decision-making, deliberation and participation, eds. Delli-Carpini, M. X., Huddy, L., and Shapiro, R. Y., 15-49. Amsterdam: JAI.

Ginsberg, B. and Shefter, M. 2002. Politics by other means: Politicians, prosecutors, and the press from Watergate to Whitewater (3rd ed.). New York: W.W. Norton and Company. 
Gonzalez, E. and Manasan, R. 2002. Social protection in the Philippines. In Social protection in Southeast and East Asia, eds. Adam, E., von Huff, M. and Marei, J., 72-76. Singapore: Friedrich Ebert Stiftung.

Gonzalez, L. E. 2008. Political crises and democracy in Latin America since the end of the Cold War. The Hellen Kellogg Institute for International Studies working paper no. 353, Kellogg Institute for International Studies, Notre Dame, Indiana.

Gonzales, L. 2014. Unpacking delegative democracy: Digging into the empirical content of a rich theoretical concept. In Reflections on uneven democracies: The legacy of Guillermo O'Donnell, eds. Brinks, D., Leiras, M. and Mainwaring, S., 240-268. Baltimore, MD: John Hopkins University Press.

Green, D., Zelizer, A. and Kirby, D. 2018. Publicizing scandal: Results from five field experiments. Quarterly Journal of Political Science 13 (3): 237-261. https://doi.org/10.1561/100.00017094

Guiogona, R. 2015. An overview of the mass media situation in the Philippines. Media Ownership Monitor, Reporters without Borders. http://philippines. mom-rsf.org/en/library/?tx_lfrogmom_library\%5Baction $\% 5 \mathrm{D}=$ show\&tx _lfrogmom_library\%5Bcontroller\%5D=Document\&tx_lfrogmom _library\%5Bdocument\%5D=629\&cHash=1b6cde2bdb6fe28124bbb4592631322c.

Hamilton, J. T. 2004. All the news that's fit to sell: How the market transforms information into news. Princeton, NJ: Princeton University Press.

Hart, P., Tindall, K. and Brown, C. 2009. Crisis leadership of the Bush presidency: Advisory capacity and presidential performance in the acute stages of the $9 / 11$ and Katrina crises. Presidential Studies Quarterly 39. https://doi.org/10.1111/j.1741 $-5705.2009 .03687 . \mathrm{x}$

Hedman, E. E. 2010. The politics of public opinion in the Philippines. Journal of Current Southeast Asian Affairs 29 (4): 97-118. https://doi.org/10.1177/ 186810341002900405

Henning, C. R. 2011. Economic crises and institutions for regional economic cooperation. Asian Development Bank working paper series on Regional Economic Integration no. 81. Mandaluyong City, Philippines, Asian Development Bank (ADB).

Hernandez, E. and Kriesi, H. 2016. The electoral consequences of the financial and economic crisis in Europe. European Journal of Political Research 55: 203-224. https://doi.org/10.1111/1475-6765.12122

Hester, J. B. and Dougall, E. 2007. The efficiency of constructed week sampling for content analysis of online news. Journalism and Mass Communication Quarterly 84: 811824. https://doi.org/10.1177\%2F107769900708400410

ISAAA. 2017. From fear to facts: 17 years of agri-biotech reporting in the Philippines (2000-2016). https://www.isaaa.org/resources/publications/fromfeartofacts/ download/From_Fear_to_Facts.pdf.

Iyengar, S. and Hahn, K. S. 2009. Red media, blue media: Evidence of ideological selectivity in media use. Journal of Communication 59: 19-39. https://doi.org/ 10.1111/j.1460-2466.2008.01402.x

Jaca, G. B. 2016. "Consolidated" democracy? Persistence of elite and money politics in the Philippines and Indonesia. Paper presented at the De La Salle University (DLSU) Research Congress 2016. 
Jerit, J. and Barabas, J. 2012. Partisan perceptual bias and the information environment. The Journal of Politics 74 (3): 672-684. https://doi.org/10.1017/ s0022381612000187

Kasuya, Y. 2003. Weak institutions and strong movements: The case of President Estrada's impeachment and removal in the Philippines. In Checking executive power: Presidential impeachment in comparative perspective, eds. Baumgartner, J. and Kada, N., 45-63. Westport, CT: Praeger Publishers.

2005. Patronage of the past and future: Legislators' decision to impeach President Estrada of the Philippines. The Pacific Review 18 (4): 521-540. https://doi.org/ $10.1080 / 09512740500338994$

Kawanaka, T. 2010. Interaction of powers in the Philippine presidential system. Institute of Developing Economies (IDE) discussion paper no. 233, Japan External Trade Organization (JETRO).

Kellner, D. 1981. Network television and American society: Introduction to a critical theory of television. Theory and Society 10: 31-62. https://doi.org/10.1007/BF00209562

Lande, C. H. 1965. Leaders, factions, and parties: The structure of Philippine politics. Yale: Yale University.

Linz, J. J. 1990. The perils of presidentialism. Journal of Democracy 1: 51-69.

Luke, D. A. and Caburnay, C. A. 2011. How much is enough? New recommendations for using constructed week sampling in newspaper content analysis of health stories. Communication Methods and Measures 5 (1): 76-91. https://doi .org/10.2307/254438

Marinova, D., Anduiza, E. and Cat, E. 2018. Information acquisition in times of economic crisis. Political Behaviour 42: 465-486. https://doi.org/10.1007/s11109 $-018-9503-3$

Markovits, A. S. and Silverstein, M. 1988. Politics of scandal: Power and process in liberal democracies. Teaneck, NJ: Holmes and Meier Publishers.

Marshall, W. P. 2008. Eleven reasons why presidential power inevitably expands and why it matters. Boston University Law Review 505. https://ssrn.com/abstract=2649959.

Maslog, C. C. et al. 2015. The political economy of the news media in the Philippines and the framing of news stories on the GPH-CNN peace process. Noref Norweigan Peacebuilding Resource Centre report.

Mindich, D. T. M. 1998. Just the facts: How objectivity came to define American journalism. New York: New York University Press.

Mirandilla, M. G. P. 2009. Cybercampaigning for 2010: The use and effectiveness of websites and social networking sites as campaign platforms for the 2010 Philippine presidential election. Paper presented at the 4th Communication Policy Research: South Conference, Negombo, Sri Lanka.

Navarro, M. et al. 2011. Print media reportage of agricultural biotechnology in the Philippines: A decade's (2000-2009) analysis of news coverage and framing. Journal of Science Communication 10 (3): 1-12. https://doi.org/10.22323/2 .10030201

Neustadt, R. E. 1990. Presidential power and the modern presidents: The politics of leadership from Roosevelt to Reagan. New York: Free Press. 
Newman, B. and Forcehimes, A. 2010. "Rally round the flag" events for presidential approval research. Electoral Studies 29 (1): 144-154. https://doi.org/10.1016/ j.electstud.2009.07.003

Nidoy, M. G. and Manalo IV, J. A. 2018. Rice stories in the mainstream media: The case of PhilRice. Philippine Journal of Crop Science 43: 46-55.

The Nielsen Company. 2015. 2015 first quarter consumer and media view survey. https://www.nielsen.com/?s=2015+First+Quarter+Consumer+and+Media + View + Survey. $+\&$ market $=$ eu $\&$ language $=$ en $\&$ orderby $=\&$ order $=\& y$ ear $=\&$ insight_categories $=\&$ insight_related_tags $=\&$ formats $=$.

Nyhan, B. 2014. Scandal potential: How political context and news congestion affect the president's vulnerability to media scandal. British Journal of Political Science 45 (2): 435-466. https://doi.org/10.1017/S0007123413000458

2017. Media scandals are political events: How contextual factors affect public controversies over alleged misconduct by U.S. governors. Political Research Quarterly 70 (1): 223-236. https://doi.org/10.1177\%2F1065912916684034

O’Donnell, G. 1994. Delegative democracy. Journal of Democracy 5: 55-69. https://doi.org/10.1353/jod.1994.0010

Panao, R. A. L. 2014. Beyond roll call: Executive-legislative relations and lawmaking in the Philippine House of Representatives. Philippine Political Science Journal 35 (1): 59-77. https://doi.org/10.1080/01154451.2014.903554

. 2019. Competing legitimacy, legitimated control: Public approval and presidential ordinance power in the Philippines, 1987 to 2016. Paper presented at the International Conference on South East Asian Studies, Wenzao Ursuline University of Foreign Languages, Kaohsiung, Taiwan, 17-19 October.

Parker, D. C. W. and Dull, M. 2009. Divided we quarrel: The politics of congressional investigations, 1947-2004. Legislative Studies Quarterly 34 (3): 319-45. https://doi.org/10.3162/036298009788897790

Pereira, M. and Waterbury, N. 2018. Do voters discount political scandals over time. Political Research Quarterly 72 (2): 584-595. https://doi.org/10.1177 \%2F1065912918795059

Perez-Linan, A. 2007. Presidential impeachment and the new political instability in Latin America. New York: Cambridge University Press.

Pertierra, R. 2012. The new media, society and politics in the Philippines. Berlin: FriedrichElbert-Stiftung Institute.

Taber, C. and Lodge, M. 2006. Motivated skepticism in the evaluation of political beliefs. American Journal of Political Science 50: 755-769. https://doi.org/10.1111/j $.1540-5907.2006 .00214 . x$

Reyes-Housholder, C. 2019. A theory of gender's role on presidential approval ratings in corrupt times. Political Research Quarterly 3: 1-16. https://doi.org/10 $.1177 \% 2 \mathrm{~F} 1065912919838626$

Riffe, D., Lacy, S. and Fico, F. G. 1993. The effectiveness of random, consecutive day, and constructed week sampling in newspaper content analysis. Journalism and Mass Communication Quarterly 70: 133-139. https://doi.org/10.1177\% 2F107769909307000115 2006. Analysing media messages: Using quantitative content analysis in research. New Jersey: Lawrence Edbaum. 
Robinson, M. J. 2007. The news interest index, 1986-2007. Pew Research Centre for the People and the Press, 15 August.

Rottinghaus, B. 2015. The institutional effects of executive scandal. New York: Cambridge University Press.

Seraca, G. G. 2018. Putting a face on the Philippines' drug war. Asian Politics and Policy 10 (1): 154-159. https://doi.org/10.1111/aspp.12371

Shugart, M. S. 2006. Comparative executive-legislative relations. In The Oxford handbook of political institutions, eds. Rhodes, R. A. W., Binder, S. and Rockman, B. A., 344-365. Oxford: Oxford University Press.

Simon, D. and Ostrom, C. 1989. The impact of televised speeches and foreign travel on presidential approval. Public Opinion Quarterly 53 (1): 53-82. https://doi.org/ $10.1086 / 269141$

Sniderman, P. 1993. The new look in public opinion research. In Political science: The state of the discipline II, ed. Finifter, A., 219-246. Washington, DC: American Political Science Association.

Solimano, A. 2005. Political crisis, social conflict, and economic development: The political economy of the Andean Region. London: Edward Elgar Press.

Thompson, J. 2000. Political scandal: Power and visibility in the media age. Cambridge: Polity Press.

Thompson, M. R. 2014. The politics Philippine presidents make. Critical Asian Studies 46 (3): 433-460. https://doi.org/10.1080/14672715.2014.935135

Waisbord, S. R. 2004. Scandals, media, and citizenship in contemporary Argentina. American Behavioral Scientist 47 (8): 1072-1098. https://doi.org/10.1177 $\% 2 \mathrm{~F} 0002764203262278$

Żemojtel-Piotrowska, M. A. et al. 2016. Corruption and sexual scandal: The importance of politician gender. Anales De Psicología [Annals of Psychology] 33 (1): 133-141. https://doi.org/10.6018/analesps.32.3.229171 